\title{
Assessment of noise level of a medium scale thermal power plant
}

\begin{abstract}
Noise monitoring using "Cirrus sound level" was carried out for $30 \mathrm{~min}$ at a height of $1.5 \mathrm{~m}$ and $1 \mathrm{~m}$ away from the chest during October, 2002 covering 73 locations of $\sim 781$ MW power plant. Event Leq and LN cycle were studied to identify the noisy machines and to generate baseline data. Lowest avg. noise $70.37 \mathrm{~dB}(\mathrm{~A})$ was found at control room while the highest avg, $95.91 \mathrm{~dB}(A)$ at $F$. D. Fan with average $88.04 \pm 6.08 \mathrm{~dB}(\mathrm{~A})$. Compressors generate second highest noise, $89.98 \mathrm{~dB}(\mathrm{~A})$. Operators of F.D. Fans are having a fare chance of exposure with $>90 \mathrm{~dB}(\mathrm{~A})$ i.e., beyond the prescribed standard. Noise may not jeopardize employee's life immediately but might be the cause of neurobehavioral change, psychological stress and unhappiness in daily life without showing the symptoms of chronic /acute diseases. Measured data has been compared with TLV of American Conference of Governmental Industrial Hygienists. The quality of life of industrial worker is one of the prime factors for production; hence it should not be neglected. Revision of occupational Indian noise standard is recommended at par with International / European standards. Noise-reducing options are also described. This investigation may help the implementing authority to adopt better policy for better work environment.
\end{abstract}

Key words: Acoustic treatment, health hazard, noise measurements, thermal power plant exposure. However, prolong exposure to industrial noise can't be neglected which may be the cause of neurobehavioral change, psychological stress and unhappiness in daily life without showing the symptoms of chronic / acute diseases. ${ }^{[2]}$

Since, the ears have no natural device to check or protect it from noise, it has no option but to receive all the sound that strikes the eardrum. In industry, excessive noise exposure can cause both auditory and extra-auditory effects. The most important of these is hearing damage resulting from prolonged exposure to excessive noise. ${ }^{[3]}$ Another undesirable effect is speech interference or interruption of communication. Annoyance is a third undesirable effect of noise. ${ }^{[4]}$

The damaging effect on hearing depends on (1) the level and spectrum of the noise, (2) duration of exposure, (3) how many times it occurs per day, (4) over how many years daily exposure is repeated, (5) the effects on hearing regarded as damage and (6) individual susceptibility to this type of injury.

\section{INTRODUCTION}

Life is powered by the coal-fired thermal power plant that contributes $72 \%$ (72000 MW) of the total power generation (104917 MW) in India. The share of hydel power is around 25$30 \%$ (25000 MW) while the rest $3-5 \%$ is due to nuclear power and wind resources. ${ }^{[1]}$ Thermal power plant is one of the noisiest factories.

Ambient air monitoring, stack emission monitoring, water and effluent testing are mandatory to compliance the needs of pollution control board to run the industry. Many industrial authorities as well as pollution control boards do not give due weightage to the problem of noise pollution because it does not jeopardize employee's life immediately after
At first, excessive exposure to harmful noise causes auditory fatigue or a temporary threshold shift (TTS). However, repeated insults of excessive noise can transform this TTS into a permanent threshold shift. Auditory effects like noise-induced hearing loss can happen unnoticed over a period of years. The extraauditory effects of noise result in physiologic changes other than hearing. Laboratory studies have shown that noise reduces efficiency
G. C. Kisku, S. K. Bhargava Environmental Monitoring Division, Industrial Toxicology Research Centre, MG Marg, Post Box No. 80, Lucknow - 226 001, UP, India

For correspondance: Dr. GC Kisku, Environmental Monitoring Division, Industrial Toxicology Research Centre, MG Marg, Post Box No. 80 , Lucknow - 226001 , UP, India. E-mail: kiskugc1@rediffmail.com

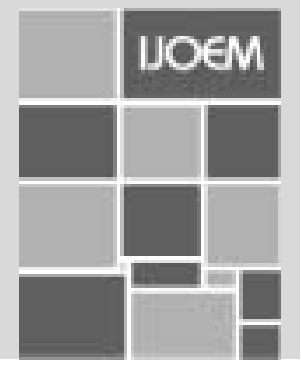


on some tasks, can upset the sense of balance and can cause blood vessels to constrict, raising blood pressure and reducing the volume of blood flow. It causes the pupils of the eyes to dilate. Even when we are sleeping, noise can cause changes in electro-encephalograms and blood circulation without waking us. It can also cause fatigue, nervousness, irritability and hypertension and add to the overall stress of living. ${ }^{[5-11]}$

The prime objectives of this present study is to identify the major sources/noise producing machines of the thermal power plant, to generate baseline data with regard to different machines and to assess the possible health effect on the workers working in the high noise zone based on the threshold limit of American Conference of Governmental Industrial Hygienists.

\section{Geographical position of the plant}

A $781 \mathrm{MW}$ plant is in Sonebhadra (latitude $24^{\circ} 10^{\prime}-24^{\circ} 12^{\prime} \mathrm{N}$ and longitude $82^{\circ} 46^{\prime}-82^{\circ} 48^{\prime} \mathrm{E}$ ) in Uttar Pradesh, located besides the Varanasi - Shaktinagar Highway, $\sim 15 \mathrm{~km}$ from Shaktinagar and $5 \mathrm{~km}$ from Anpara Railway Station in a remote semi-industrial developed and coal mine area. Rihand reservoir is the only surface water body flowing from NorthEast to South-West direction, guarded by rocky hilly terrains and fly ash bund. Hill slopes are generally covered with thin vegetation. The plant has the plant load factor $>88$ which is exceptionally high in comparison to average national plant load factor.

\section{Characteristics and transportation of raw material} Coal is the raw material of a thermal power plant transported through aerial rope ways and dumpers from the adjacent Jhingurda mine of Singrauli coal belt of Northern Coal Ltd. The last five year figures of coal consumption ranged between 35-45 MT. Coal, moisture content $15-18 \%$, ash $32-41 \%$, volatile carbon $19-23 \%$, fixed carbon $21-27 \%$ and caloric value $2800-$ $3400 \mathrm{kcal} / \mathrm{kg}$.

\section{Electricity generation process}

The coal chunk is brought from the mine to unloading station of coal handling plant and ultimately passes to crusher house for sizing. The coal then passes to open storage and coal bunkers in the plant, which feed coal to mills for pulverization process. Pulverized coal is fed directly into the boiler through forced draft fan. Demineralized water (DM water avoids scaling/ corrosion in the boiler which reduce the efficiency) is used as make-up water for the power cycle. Pressure of the steam generated in the boiler is increased by air compressors that rotate the turbine and converts mechanical power to electrical energy with the help of a device called Alternator.

\section{METHODOLOGY OF NOISE MEASUREMENTS AND MONITORING LOCATIONS}

\section{Survey techniques}

Cirrus sound level meter, model 236 A, UK make sensitive to sound pressures between 20 and $20000 \mathrm{~Hz}$ was used to measure the noise level. Calibrated instrument was transported in a brief case containing sponge groove that protect from vibration and shock. The range and sensitivity of the instrument is $32-140 \mathrm{~dB}(\mathrm{~A})$ with accuracy $\pm 5 \% \cdot{ }^{[12]}$ The noise level was recorded at a distance of 5-10 feet on the basis where cumulative noise was expected from different sources or at operator. Monitoring was done at a height of $1.5 \mathrm{~m}$ and 1 $\mathrm{m}$ away from the chest for $30 \mathrm{~min}$ at an interval of $15 \mathrm{~s}$.

\section{Principles of Leq}

The short Leq (equivalent continuous sound level) concept was proposed by Komorn and Luquet. ${ }^{[13]}$ Leq is the level which, if maintained constant for the same period as the measurement, would contain the same amount of energy as the fluctuating noise level. It is measured directly by an integrating averaging sound level meter. It is a linear integration over time. The formula used for leq calculation is given below in the form it appears in the international standard IEC 804.

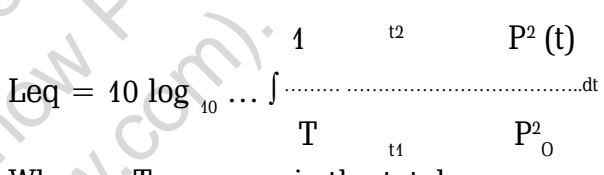

Where T......... is the total measurement time. $\mathrm{PA}^{(t)} \ldots . . .$. is the A-weighted instantaneous acoustic pressure. and Po .........is the reference acoustic pressure (20 $\mu \mathrm{PA})$.

Leq is used as the basis for calculating $\mathrm{L}_{\mathrm{DP}}$ (day-night average sound level) and $\mathrm{L}_{\mathrm{NP}}$ (noise pollution level). Among A-weighting (ears response to sounds near the $40 \mathrm{~dB}$ level), B-weighting (near $70 \mathrm{~dB}$ ), C-weighting (near $100 \mathrm{~dB}$ ) and D-weighting (jet plane noise) measuring scales, the A-weighting is the commonly used scale to measure steady sound levels. ${ }^{[14]}$

\section{Monitoring locations}

After primary walk through the survey, 73 locations of plant area had been identified based on the maximum sound pressure for noise measurements. These locations are shown in Table 1 along with short description of the noise sources and the specific function of the noise source/machines. These are coal unloading plant-2, coal crusher plant- 3, compressor - 5, boiler feed pump-7, operator sitting place for boiler feed pump-7, control room-4, operator sitting place-2, turbine -8 , boiler operating room-7, boiler operator sitting place-1, F. D. fan-8, I. D. fan-9, operator sitting place of I. D. fan-6, D. M. plant-1, cooling tower-1, operator sitting place for cooling tower-1, aerial rope way-1. Besides the above major sources which contribute $\sim 80 \%$ noise, the remaining noise might be attributed to the background noise generated from incoming /outgoing vehicles, servicing and repairing, minor construction, office work etc. 
Table 1: Monitoring locations, noise sources and particular function of the machines

\begin{tabular}{|c|c|c|c|}
\hline Monitoring location & No. & Source of noise & Specific function \\
\hline Coal unloading plant & 2 & Dumpers & Unload the coal. \\
\hline Coal crusher plant & 3 & Crusher mill & Crushes coal into pulverized to increase the burning efficiency. \\
\hline Compressors & 5 & Compressors & Increase the steam pressure before inject into the turbine. \\
\hline Boiler feed pump & 7 & Boiler feed pump & Pulverized coal is fed directly into the boiler through force draft fan. \\
\hline Operator sitting place of boiler feed pump & 7 & Turbine & $\begin{array}{l}\text { Turbine is a machine which rotates itself by the force of inject high } \\
\text { pressure steam and then does conversion of kinetic energy into } \\
\text { mechanical work to electrical energy. }\end{array}$ \\
\hline Control room & 4 & & \\
\hline Operator sitting place & 2 & & \\
\hline Turbine & 8 & & \\
\hline Boiler operating room & 7 & Boiler & Produce steam for the power plant. \\
\hline Boiler operator sitting place & 1 & F. D. fan & Pulverized coal has been inducted directly into the boiler. \\
\hline Forced draft fan (FD fan) & 8 & & \\
\hline Induced draft fan (ID fan) & 9 & I. D. fan & Help flue gas to exit through chimney. \\
\hline Operator sitting place of I. D. fan & 6 & D. M. plant & $\begin{array}{l}\text { Produce demineralized water to avoid scaling and heating loss in the } \\
\text { boiler. }\end{array}$ \\
\hline Demineralized plant & 1 & & \\
\hline Cooling tower & 1 & Cooling tower & $\begin{array}{l}\text { Heated steam condensed into water molecules and recycled and } \\
\text { reuse. }\end{array}$ \\
\hline Operator sitting place of cooling tower & 1 & & \\
\hline Aerial rope way & 1 & Aerial rope way & $\begin{array}{l}\text { Carry coal through ropeway from coalmines to coal handling plant } \\
\text { automatically. }\end{array}$ \\
\hline
\end{tabular}

\section{RESULTS AND DISCUSSION}

The observed noise levels recorded during survey work for different machines and locations are presented in Tables 2 and 3 respectively. SLM recorded noise in the form of Event Leq and $\mathrm{L}_{\mathrm{N}}$ cycle. $\mathrm{L}_{\mathrm{N}}$ cycle represents that N\% of the time, the noise level was below the given value of $\mathrm{X}$ viz. Compressor No. 1: $\mathrm{L}-1$ represents that $1 \%$ of the measured time the noise level was above $100.6 \mathrm{~dB}(\mathrm{~A})$ and L-99 represents that $99 \%$ of the measured time the noise level was below $86.2 \mathrm{~dB}(\mathrm{~A})$ [Table 2].

\section{Coal unloading plant}

Among the two coal unloading plants, minimum Leq, 87.8 $\mathrm{dB}(\mathrm{A})$ was recorded near unloading plant-1 and while the maximum Leq, $90.1 \mathrm{~dB}(\mathrm{~A})$ was recorded near unloading plant2 with an log average Leq $89.10 \pm 1.63 \mathrm{~dB}(\mathrm{~A})$ [Table 2].

\section{Coal crusher plant}

The minimum Leq, $85.8 \mathrm{~dB}(\mathrm{~A})$ was found at crusher plant-2 while the maximum Leq, 93.7 $\mathrm{dB}(\mathrm{A})$ was found near crusher plant-1. The log average. Leq of crusher plants was $90.28 \pm 4.30 \mathrm{~dB}(\mathrm{~A})$ which is higher than the prescribed standard of $90 \mathrm{~dB}(\mathrm{~A})$ [Tables 2 and 4].

\section{Compressor noise}

The minimum event Leq, $87 \mathrm{~dB}(\mathrm{~A})$ was recorded near Compressor-3 and while the maximum event Leq, 93.6 dB(A) was recorded near compressor-1 with log average Leq. $90.54 \pm 2.41 \mathrm{~dB}(\mathrm{~A})$. All the compressors were producing noise level which touches the maximum permissible limit of 90 $\mathrm{dB}(\mathrm{A})$ for $8 \mathrm{~h}$. Especially compressor-1 showed levels beyond the maximum permissible limit of $90 \mathrm{~dB}(\mathrm{~A})$ for $8 \mathrm{~h} / \mathrm{day}$. [Table 2]. Compressors generated second highest log. average Leq $89.98 \mathrm{~dB}(\mathrm{~A})$ noise level after the F.D. Fan with log average Leq $95.91 \pm 6.15 \mathrm{~dB}(\mathrm{~A})$ [Table 2]. These data do not fall in the safe zone for occupational environment $;$ out of 5 compressors; 2 were producing beyond the permissible limit of $90 \mathrm{~dB}(\mathrm{~A})$ [Table 4].

\section{Boiler feed pump (BFP)}

The minimum event Leq, $87.5 \mathrm{~dB}(\mathrm{~A})$ was recorded near BFP$5 \mathrm{~A}$ and while the maximum event Leq, $92.4 \mathrm{~dB}(\mathrm{~A})$ was recorded at BFP-3B with log average Leq $89 \pm 1.76 \mathrm{~dB}(\mathrm{~A})$ [Table 2]. All the BFPs were producing noise level which touched the maximum permissible limit of $90 \mathrm{~dB}(\mathrm{~A})$, especially; $\mathrm{BFP}-3 \mathrm{~B}$ showed beyond the maximum permissible limit of $90 \mathrm{~dB}(\mathrm{~A})$ for $8 \mathrm{~h} /$ day.

\section{Turbine}

The noise level found between 74.9-86.0 dB(A) with log average Leq $83.41 \pm 3.82 \mathrm{~dB}(\mathrm{~A})$. The lowest was measured for turbine No. 6 while highest for turbine No. 2 and 8. Turbine sound pressure is lesser than F.D. fan, boiler feed pump but higher than I. D. fan and cooling tower. It produced almost equivalent sound pressure of DM plant and aerial rope way [Table 2].

\section{F. D. fan}

The minimum event Leq, $83.8 \mathrm{~dB}(\mathrm{~A})$ was recorded for F.D. fan No. $1 \mathrm{~A}$ and while the maximum event Leq, $103 \mathrm{~dB}(\mathrm{~A})$ was recorded for F. D. Fan No. 6A. with log average Leq 95.91 \pm 6.15 $\mathrm{dB}(\mathrm{A})$. F. D. Fans were the noisiest one among the power plants. F. D. Fan Nos. 2A, 3A, 4A, 5A, 7A and 9A produced noise level of about $85.7,95.8,94.9,88.6,92.7$ and $90.5 \mathrm{~dB}(\mathrm{~A})$ respectively [Table 2]. 
Table 2: Noise levels $\mathrm{dB}(\mathrm{A})$ of different machines of a thermal power plant

\begin{tabular}{|c|c|c|c|c|c|c|c|c|}
\hline \multirow[t]{2}{*}{ Monitoring location } & \multicolumn{8}{|c|}{ Noise level in $\mathrm{dB}(\mathrm{A})$} \\
\hline & L-1 & L-5 & L-10 & L-50 & L-90 & L-95 & L-99 & Leq. \\
\hline \multicolumn{9}{|l|}{ Coal unloading plant } \\
\hline Unloading plant - 1 & 91.4 & 90.5 & 89.7 & 88.7 & 87.5 & 86.5 & 86.2 & 87.8 \\
\hline Unloading plant 2 & 93.5 & 92.4 & 91.6 & 89 & 88.6 & 87.7 & 87.1 & 90.1 \\
\hline \multicolumn{9}{|l|}{ Coal crusher plant } \\
\hline Crusher plant-1 & 95.6 & 94.5 & 93.2 & 92.1 & 90.3 & 89.5 & 89.2 & 93.7 \\
\hline Crusher plant- 2 & 92.3 & 91.5 & 89.8 & 87.3 & 86.8 & 86.4 & 86.2 & 85.8 \\
\hline Crusher plant- 3 & 94.1 & 90.4 & 89.6 & 88.6 & 87.9 & 87.6 & 87.4 & 86.8 \\
\hline \multicolumn{9}{|l|}{ Compressor } \\
\hline Compressor-1 & 100.6 & 87.9 & 88 & 87.3 & 86.4 & 86.2 & 86.2 & 93.6 \\
\hline Compressor-3 & 88.3 & 86.9 & 86.9 & 86.3 & 85.9 & 85.9 & 85.9 & 87 \\
\hline Compressor-5 & 90.1 & 89.5 & 88.9 & 88.5 & 88.3 & 88.3 & 88.3 & 89.3 \\
\hline Compressor-7 & 91.3 & 90.8 & 90.7 & 89.8 & 89.5 & 89.5 & 89.5 & 90.6 \\
\hline Compressor-8 & 91.9 & 90.5 & 90 & 88.6 & 88 & 88 & 87.1 & 89.4 \\
\hline \multicolumn{9}{|l|}{ Boiler feed bump (BFP) } \\
\hline BFP-1B & 88.5 & 87.9 & 85.8 & 85.1 & 84.3 & 84.3 & 84.3 & 87.6 \\
\hline BFP- 2A & 95.2 & 89.2 & 88.6 & 87.4 & 86.6 & 86.5 & 86.5 & 89.1 \\
\hline BFP- 3B & 97.6 & 96.2 & 93.8 & 91.4 & 89.2 & 89 & 88.6 & 92.4 \\
\hline BFP- 4B & 88.9 & 88.7 & 88.7 & 87.6 & 86.8 & 86.4 & 86.4 & 88.4 \\
\hline BFP- 5A & 89.6 & 88.5 & 87.6 & 86.8 & 85.9 & 85.6 & 85.6 & 87.5 \\
\hline BFP- $6 \mathrm{~A}$ & 88.9 & 87.6 & 88.2 & 86.7 & 85.1 & 84.6 & 84.6 & 87.7 \\
\hline BFP-7B & 88.9 & 88 & 87.6 & 86.7 & 85.1 & 84.6 & 84.6 & 87.7 \\
\hline \multicolumn{9}{|l|}{ Turbine floor } \\
\hline Turbine \# -1 & 86.9 & 85.9 & 85.8 & 84.7 & 84.5 & 84.1 & 84.1 & 85.3 \\
\hline Turbine \# - 2 & 89.8 & 86.8 & 86 & 84.6 & 84.2 & 84.2 & 84.2 & 86 \\
\hline Turbine \# - 3 & 87.7 & 86 & 85.5 & 84.7 & 84 & 84 & 84 & 85.8 \\
\hline Turbine \# - 4 & 84.9 & 83.9 & 84.8 & 84.1 & 83.5 & 83.5 & 83.5 & 84.6 \\
\hline Turbine \# - 5 & 87.8 & 81.3 & 84.9 & 78.8 & 76.7 & 76.3 & 76.3 & 81.1 \\
\hline Turbine \# - 6 & 76.7 & 74.9 & 74.8 & 74.2 & 74 & 74 & 74 & 74.9 \\
\hline Turbine \# -7 & 97.5 & 78.3 & 75.7 & 74.7 & 74.4 & 74.4 & 74.4 & 83.6 \\
\hline Turbine \# - 8 & 86.6 & 85.9 & 85.9 & 85.5 & 85.2 & 85.2 & 85.2 & 86 \\
\hline \multicolumn{9}{|l|}{ F. D. fan } \\
\hline F. D. fan \# - 1A & 87 & 84.8 & 84 & 82.5 & 81.8 & 81.8 & 81.8 & 83.8 \\
\hline F. D. fan \# - 2A & 90 & 86 & 85.5 & 84.5 & 84.5 & 84.5 & 84.5 & 85.7 \\
\hline F. D. fan \# - 3A & 95.9 & 95.8 & 95.5 & 95.2 & 94.9 & 94.9 & 94.9 & 95.8 \\
\hline F. D. fan \# - 4A & 95.8 & 95.2 & 94.9 & 94.2 & 93.7 & 93.7 & 93.6 & 94.9 \\
\hline F. D. fan \# - 5A & 90.3 & 88.7 & 87.9 & 87.6 & 87.4 & 87.4 & 87.4 & 88.6 \\
\hline F. D. fan \# - 6 A & 103.8 & 102.7 & 102.8 & 102.3 & 101.7 & 101.7 & 101.7 & 103 \\
\hline F. D. fan \# - 7A & 92.9 & 92.9 & 92.8 & 92 & 91.9 & 91.8 & 91.7 & 92.7 \\
\hline F. D. fan \# - 9A & 92.1 & 90.7 & 91 & 89.6 & 89.3 & 89.3 & 89.3 & 90.5 \\
\hline \multicolumn{9}{|l|}{ I. D. Fan } \\
\hline I. D. fan \# - 1A & 81 & 78.1 & 77.7 & 76.6 & 76.2 & 76.2 & 76.2 & 77.7 \\
\hline I. D. fan \# - 2A & 82.5 & 79.3 & 76.9 & 76.8 & 75.8 & 75.8 & 75.8 & 78.7 \\
\hline I. D. fan \# - 3A & 85.7 & 81.8 & 81.9 & 80.6 & 80.2 & 80.2 & 80.2 & 81.7 \\
\hline I. D. fan \# - 4A & 86.7 & 81.9 & 84.8 & 81.6 & 80.3 & 80.7 & 80.7 & 82.7 \\
\hline I. D. fan \# - $5 \mathrm{~A}$ & 85.6 & 83.5 & 83.2 & 82.6 & 82.1 & 82.1 & 82.1 & 83.8 \\
\hline I. D. fan \# - 6A & 81.9 & 78.8 & 79.3 & 77.9 & 77.6 & 77.6 & 77.6 & 79.1 \\
\hline I. D. fan \# - 7A & 85.3 & 80.9 & 81.3 & 80.1 & 79.4 & 79.4 & 79.4 & 81.4 \\
\hline I. D. fan \# - 9A & 88.6 & 87.8 & 85.6 & 82.6 & 80.6 & 80.2 & 80 & 83.4 \\
\hline I. D. fan \# - 9A & 85.6 & 85.5 & 84.5 & 82.1 & 81 & 80.7 & 80.7 & 82.8 \\
\hline \multicolumn{9}{|l|}{ D. M. plant } \\
\hline \multicolumn{9}{|c|}{ Closed-...... Not Functioning } \\
\hline D. M. plant \# 2 & 83.9 & 83.8 & 83.6 & 82.8 & 82.8 & 82.8 & 82.8 & 83.6 \\
\hline \multicolumn{9}{|c|}{ Closed-...... Not Functioning } \\
\hline \multicolumn{9}{|l|}{ Cooling tower } \\
\hline Cooling tower No. 1 & 78.7 & 74.9 & 75.7 & 74.5 & 74.5 & 74.5 & 74.5 & 75.8 \\
\hline Cooling tower No. 2 & $-\ldots \ldots N$ & & & & & & & \\
\hline Cooling tower No. 3 & -...... N & & & & & & & \\
\hline \multicolumn{9}{|l|}{ Aerial rope way } \\
\hline Mono cable & 85.5 & 84.8 & 84.2 & 83.9 & 83.9 & 83.9 & 83.9 & 84.7 \\
\hline
\end{tabular}


Table 3: Noise levels $\mathrm{dB}(\mathrm{A})$ at different locations of a thermal power plant

\begin{tabular}{|c|c|c|c|c|c|c|c|c|}
\hline \multirow[t]{2}{*}{ Monitoring location } & \multicolumn{8}{|c|}{ Noise level in $\mathrm{dB}(\mathrm{A})$} \\
\hline & L-1 & L-5 & L-10 & L-50 & L-90 & L-95 & L-99 & Leq. \\
\hline \multicolumn{9}{|c|}{ Operator sitting place (OSP) for boiler feed pump } \\
\hline OSP - 1 & 88.7 & 84.8 & 83.9 & 83.1 & 82.8 & 82.8 & 82.8 & 83.7 \\
\hline OSP - 3 & 81.9 & 81.5 & 80.9 & 80.5 & 80.4 & 80.4 & 80.4 & 81.2 \\
\hline OSP - 4 & 87.2 & 82.7 & 81.9 & 81.5 & 81.2 & 81.2 & 81.2 & 82.5 \\
\hline OSP - 5 & 83.6 & 82.5 & 81.9 & 79.8 & 78.1 & 78 & 78 & 81 \\
\hline OSP - 6 & 85.9 & 83.9 & 83.8 & 83.1 & 82.7 & 82.7 & 82.7 & 84 \\
\hline OSP - 7 & 97.8 & 96.7 & 94.9 & 94.3 & 93.1 & 93.1 & 93.1 & 94.8 \\
\hline OSP - 8 & 85.2 & 81.3 & 81.3 & 80.5 & 80.5 & 80.5 & 80.5 & 82.3 \\
\hline \multicolumn{9}{|l|}{ Control room } \\
\hline TG-8 & 78.9 & 78.2 & 76.1 & 69.1 & 65 & 64.8 & 64.8 & 72.2 \\
\hline Old control room & 78.5 & 78 & 76.5 & 70 & 65.4 & 64.3 & 63.3 & 72.5 \\
\hline TG-5 & 68.5 & 68.8 & 66.5 & 57.9 & 56.5 & 56.3 & 56.2 & 61.9 \\
\hline TG-6 & 76.3 & 71.3 & 71.2 & 63 & 58.8 & 58.8 & 58.8 & 68.8 \\
\hline \multicolumn{9}{|c|}{ Operator sitting place for turbine } \\
\hline TG-3 & 87.2 & 83.8 & 82.5 & 81.8 & 81.6 & 81.6 & 81.6 & 83.2 \\
\hline TG-4 & 88.6 & 83.3 & 81.8 & 80.7 & 80.5 & 80.5 & 80.3 & 83.1 \\
\hline \multicolumn{9}{|l|}{ Boiler operating room } \\
\hline In side room \# - 1 & 82.5 & 77.5 & 71.8 & 70.6 & 69.1 & 69 & 68.8 & 74.5 \\
\hline In side room \# - 3 & 89.5 & 87.8 & 87.8 & 86.5 & 85.8 & 85.8 & 85.8 & 87.4 \\
\hline In side room \# - 5 & 86.7 & 84.9 & 84.7 & 83.6 & 83 & 83 & 83 & 84.3 \\
\hline In side room \# - 6 & 89.6 & 86.7 & 85.8 & 82.4 & 81.7 & 81 & 81 & 84 \\
\hline In side room \# - 7 & 87.6 & 86.7 & 85.9 & 85.3 & 84.9 & 84.9 & 84.9 & 85.9 \\
\hline In side room \# - 8 & 86.6 & 83.9 & 80.7 & 79.7 & 79 & 78.8 & 78.8 & 80.9 \\
\hline In side room \# - 9 & 85.3 & 83.5 & 80.7 & 79.4 & 78.4 & 78.4 & 78.4 & 80.7 \\
\hline Operator sitting place & 94.7 & 92 & 89.1 & 79.8 & 79.4 & 79.4 & 79.4 & 85.2 \\
\hline \multicolumn{9}{|l|}{ Operator sitting place } \\
\hline I. D. fan \# - 1 A & 82.5 & 78.3 & 77.7 & 74.8 & 73.2 & 73.2 & 73.2 & 77.2 \\
\hline I. D. fan \# - 3A & 85.6 & 83.6 & 83.1 & 79.4 & 76.3 & 75 & 74.8 & 80.5 \\
\hline I. D. fan \# - 5A & 85.8 & 81.3 & 80.9 & 80.1 & 79.4 & 79.4 & 79.4 & 81.5 \\
\hline I. D. fan \# - 6 A & 83 & 77.9 & 80.7 & 77.6 & 77 & 76.9 & 76.9 & 78.8 \\
\hline I. D. fan \# - 7A & 81.9 & 80.9 & 80.7 & 79.5 & 78.8 & 78.4 & 78.4 & 79.9 \\
\hline I. D. fan \# - 9 A & 84.2 & 83.8 & 83.3 & 81.7 & 80.5 & 80.5 & 80.5 & 82.3 \\
\hline Operator sitting place & 80.6 & 79.7 & 76.1 & 70.6 & 69.1 & 68.9 & 68.9 & 73.5 \\
\hline
\end{tabular}

Table 4: Threshold limit/values for non-impulsive noise adopted in 1970 by the American Conference of Governmental Industrial Hygienists. ${ }^{[15]}$

\begin{tabular}{lc}
\hline $\begin{array}{l}\text { Durationper day, } \\
\text { hours }\end{array}$ & $\begin{array}{c}\text { Permissible } \\
\text { sound level, dB(A) }\end{array}$ \\
\hline 8 & 90 \\
6 & 92 \\
4 & 95 \\
3 & 97 \\
2 & 100 \\
$1 / 12$ & 102 \\
1 & 105 \\
$3 / 4$ & 107 \\
$1 / 2$ & 110 \\
$1 / 4$ & 115 max. \\
\hline
\end{tabular}

\section{D. fan}

The minimum event Leq $77.7 \mathrm{~dB}(\mathrm{~A})$ was recorded for I.D. fan No. $1 \mathrm{~A}$ while the maximum event Leq, $83.8 \mathrm{~dB}(\mathrm{~A})$ was recorded for I. D. fan No. 5A with log average Leq 81. $71 \pm 2.22 \mathrm{~dB}(\mathrm{~A})$. I.D. fan is comparatively better than F. D. fans in terms of noise level [Table 2].

\section{M. plant, cooling tower and aerial rope way (Mono}

cable)

The level of noise of D.M. plant was $83.6 \mathrm{~dB}(\mathrm{~A})$. The event Leq of cooling tower was $75.8 \mathrm{~dB}(\mathrm{~A})$, which was quite calm w.r. t. others. At operator sitting place for cooling tower, the noise level was felt $73.5 \mathrm{~dB}(\mathrm{~A})$. The noise level of aerial rope way (Mono cable) was $84.7 \mathrm{~dB}(\mathrm{~A})$ [Table 2].

\section{Operator sitting place (OSP) for boiler feed pump}

The minimum event Leq, $81 \mathrm{~dB}(\mathrm{~A})$ was recorded at 0 SP- 5 and while the maximum event Leq, 94.8 $\mathrm{dB}(\mathrm{A})$ was recorded at OSP-7 with log average Leq $87.69 \pm 4.80 \mathrm{~dB}(\mathrm{~A})$. All the noise levels measured in these places were $\geq 81 \mathrm{~dB}(\mathrm{~A})$. The operator seated at OSP-7 position was exposed to noise level beyond the permissible limit of $90 \mathrm{~dB}(\mathrm{~A})$ [Table 3].

\section{Control room}

The noise level ranged between 61.9-72.5 $\mathrm{dB}(\mathrm{A})$ with $\log$ average Leq $90.37 \pm 4.93 \mathrm{~dB}(\mathrm{~A})$. The least sound $61.9 \mathrm{~dB}(\mathrm{~A})$ was felt at control room No. TG-5 while the maximum sound, $72.2 \mathrm{~dB}(\mathrm{~A})$ at TG-8 [Table 3].

\section{OSP for turbine, TG-3 and TG-4}

The noise level range in between 83.1-83.2 dB(A) with log 
average Leq $83.15 \pm 0.07 \mathrm{~dB}(\mathrm{~A})$. The least sound $83.1 \mathrm{~dB}(\mathrm{~A})$ was felt at TG-4 while the maximum sound, $83.2 \mathrm{~dB}(\mathrm{~A})$ at TG3 [Table 3].

\section{Boiler operating room (BOR) and OSP}

The minimum event Leq, $74.5 \mathrm{~dB}(\mathrm{~A})$ was recorded at BOR No. 1 while the maximum event Leq, 87.4 $\mathrm{dB}(\mathrm{A})$ was recorded at BOR No. 3 with log average Leq $83.92 \pm 4.30 \mathrm{~dB}(\mathrm{~A})$. However, the noise level at operator sitting place was as high as 85.2 $\mathrm{dB}(\mathrm{A})$ [Table 3].

\section{OSP for I. D. fan}

The noise level varied from 77.2-82.3 $\mathrm{dB}(\mathrm{A})$ with log average Leq $80.34 \mathrm{~dB}(\mathrm{~A})$. The minimum $77.2 \mathrm{~dB}(\mathrm{~A})$ was found at OSP$1 \mathrm{~A}$ and maximum $82.3 \mathrm{~dB}(\mathrm{~A})$ at OSP-9A [Table 3].

Descending order of $\mathrm{L}_{\mathrm{N}}$ cycle is $\mathrm{L}-1>\mathrm{L}-5>\mathrm{L}-10>\mathrm{L}-50>\mathrm{L}-$ $90>$ L-95> L-99, Leq does not show any particular position in the $\mathrm{L}_{\mathrm{N}}$ cycle. There is a much fluctuation among locations and different machines and also among same machine like ID fans, FD fans and compressors etc. The overall noise was 70.37-95.91 $\mathrm{dB}(\mathrm{A})$ with log average $88.04 \pm 6.08 \mathrm{~dB}(\mathrm{~A})$. Though it is below the prescribed standard but this level may be sufficient exposure to create a chronic health hazard problem after long exposure, since the subject exposed to high noise level may come out from the noise source after his duty hours but the physiological change and psychological stress occurred in his system. For the operator who is looking after the F.D. fans, there is a fare chance of exposure to $>90 \mathrm{~dB}(\mathrm{~A})$ noise.

Forty one per cent of bus drivers suffered from noise-induced deafness, ${ }^{[16]}$ while $50 \%$ of the workers in an amrunition factory had impaired hearing. ${ }^{[17]}$ Similarly high $\mathrm{r}^{\mathrm{r}}$ ?valence of hearing impairment was detected in the workers of a nitric acid plant. ${ }^{[18]}$ There is $80.6 \%$ prevalence of noise-induced hearing loss in the workers of petroleum industries. ${ }^{[19]}$

However, there is no unsteady / impulse noise in the power plant which affect more adversely than steady noise. Indian noise standards are also high than the standards for other countries.For example, the working hours in Belgium, Denmark, France, Sweden and Soviet Union (Russia) are 40 $\mathrm{h} /$ week but in case of India there are six working days in a week, so the total exposure hours are 48h/week [Table 5]. Hence, revision of the standard is required at par with the international/ European standard.

\section{RECOMIMENDATIONS}

\section{Green belt design (GBD)}

A wide green belt of thick vegetation can be produced around the factory premises. This will absorb to a large extent and
Table 5: Occupational noise standards for various countries. ${ }^{[20]}$

\begin{tabular}{lcc}
\hline Country & $\begin{array}{c}\text { Maximum permissible } \\
\text { noise level dB(A) }\end{array}$ & $\begin{array}{c}\text { Time of } \\
\text { exposure }\end{array}$ \\
\hline Australia & 80 & $8 \mathrm{~h} /$ day \\
Belgium & 80 & $40 \mathrm{~h} /$ week \\
Denmark & 90 & $40 \mathrm{~h} /$ week \\
France & 85 & $40 \mathrm{~h} /$ week \\
Germany & 85 & $8 \mathrm{~h} / \mathrm{day}$ \\
India & 90 & $8 \mathrm{~h} / \mathrm{day}$ \\
Singapore & 80 & $8 \mathrm{~h} /$ day \\
Sweden & 85 & $40 \mathrm{~h} /$ week \\
Soviet Union (Russia) & 85 & $40 \mathrm{~h} /$ week \\
USA & 90 & $8 \mathrm{~h} /$ day \\
\hline
\end{tabular}

dissipate sound energy and thus act as buffer zone. ${ }^{[21]} \mathrm{A}$ tree belt $50 \mathrm{~m}$ wide and of different height can reduce the noise level up to $20-30 \mathrm{~dB}(\mathrm{~A}){ }^{[22]}$ GBD will reduce the noise intensity by creating obstruction in its transmission path. In addition, it can decrease substantial amount of the air pollution load. Vegetation plays a positive role for our eyesight potential and GBD also regulates the temperature through transpiration. GBD also purifies the atmosphere to a significant level by utilizing $\mathrm{CO}_{2}$ produced in the power plant and releasing $\mathrm{O}_{2}$ during photosynthesis and enhances the aesthetic beauty.

\section{Sound abscibing material}

Noise pollution should not be neglected since production in a factory depends on the individual health of the employees. Outer surfaces of control room should be covered with sound absorbent material e.g., glass wool covered with perforated aluminum sheet. Glass wool is of different types and has different density. Higher the density, more is the absorbing capacity. This has practically been done in a research laboratory to reduce the noise level. However, glass wool has been banned in USA/E.U. for non-essential uses. Multiple wall construction with enclosed air spaces, provides considerably more attenuation than the single-wall mass law would predict. ${ }^{[22]}$

The absorptivity or coefficient of sound absorption is equal to that percentage of the incident sound, which is not absorbed. Table 6 lists typical coefficient of absorption for some building materials. These hard materials absorb only a few percent of the sound striking them. They can be good sound barriers, since they do not allow the passage of air and can be stiff and massive enough to be effective.

Table 6: Sound absorption of building materials

\begin{tabular}{lc}
\hline Material & Coefficient of absorption \\
\hline Glass, solidly mounted at edges & 0.03 \\
Brick wall, unpainted & 0.035 \\
Hard plaster, gypsum or lime & As high as 0.04 \\
Hardwood flooring & As high as 0.04 \\
Cork or linoleum floor tile & 0.05 \\
Light weight concrete & As high as 0.07 \\
Wood Paneling & As high as 0.08 \\
\hline
\end{tabular}




\section{Fabrication of new engines}

Noise can be controlled by designing and fabricating new engines and by setting a noise limits at least 5-10 dB(A) below the prescribed standard. ${ }^{[16]}$ Transmission control may be achieved by covering room walls with acoustic tiles as sound absorbers. Supply of earplug, earmuff and cotton/ woolen to its employees help in protecting exposed person. Preferably, shifting of duty from equipment to another on alternate days as not to operate same equipment every day. Normal duty hours can be reduced at high noise generating sources. Isolated cabin is required for operator where it is not available. Employees must be made aware and educated about noise nuisance through adequate publicity. The irregular use /not use of safety measures are a common scenario in most of the industries where rules and regulations are liberal hence authority can make it mandatory to use one or other type of noise protective measures at noisy places.

\section{CONCLUSION}

This current investigation may help power plant authorities to adopt preventive measures and for deciding future strategies to combat the menace of noise pollution with scientific approach. This will ensure in providing better environment to the employees. Occupational health hazards have to be assessed by an expert agency, which also correlates noise pollution and health hazards. Science and technology have not reached up to the level by which soundless machine can be made but the preventive measures could be adopted for prevention, abatement and control of substantial amount of noise level.

\section{REFERENCES}

1. Chandra A, Chandra H. Environmental management for clean power generation of Thermal power plants: An Indian Perspective. Indian J Air Poll Contr 2003;7:22-36.

2. Lusk SL, Hagerty BM, Gillespie B, Caruso CC. Chronic effects of workplace noise on blood pressure and Heart rate. Arch Environ Health 2002;57:273-81.

3. Crocker MJ, Price J. Noise and noise control. 18901. CRC Press Inc: Cranwood Parkway, Cleveland, Ohio; 1975. p. 44128.

4. Singh AP, Rai RM, Bhatia MR. Effect of chronic and acute exposure to noise on physiological function in man. Int Arch Occup Environ Health 1982;50:169-74.

5. Staples SL. Human response to environmental noise. Am Psychol 1996;51:143-50.

6. NIOH. A preliminary study to enquire into the utility of temporary shift of hearing levels. Annual report. National Institute of Occupational Health: Ahmedabad; 1978. p. 136-43.

7. Glorig A. Non-auditory effects of noise exposure. sound and vibration, 27101. E. Oviatt: Ohio 1971. p. 44140.

8. Rau JG, Wooten DC. Environmental Impact analysis handbook. Mc Graw-Hill Book Company: New York, Tokyo; 1977.

9. Anticaglia JR. Noise measurement and acceptability criteria. In: the Industrial Environment -its Evaluation and Control. US Dept. of Health and Human Services, Public Health Service, Centre for Disease Control, National Institute for Occupational Safety and Health: 1973. p. 30919.

10. Botsford J. Noise measurement and acceptability criteria. In: The Industrial Environment -its Evaluation and Control, U. S. Dept. of Health and Human Services, Public Health Service, Centre for Disease Control, National Institute for Occupational Safety and Health: 1973. p. 321-31.

11. Kazi Rehan A. Noise induced hearing loss-an occupational hazard. Indian J Occup Env Med 2002;6:207-12.

12. Acoustic and Vibration measurement for industry. CRL 236 A operating manual, Cirrus Research Ltd., Acoustic House, Hunmanby: N. Yorkshire, United Kingdom; 1994. p. 1- 8.

13. Komorn A, Luquet P. Methodes de description objective d'un environment acoustique. Report to the EEC. LNE April 1979 and Internoise 1981.

14. Roberts HC. Noise pollution. In: Environmental engineers handbook. Liptak BG, editor. V-III Land pollution. Chilton Book Company: Radnor Pennsylvania; 1978.

15. Threshold Limit Values for noise, American Conference of Governmental Industrial Hygenists: Ohio; 1971.

16. Natu M, Solanki SR. Noise survey and effects on state transport bus drivers. Indian J Occup Hlth 1977;20:195-200.

17. Chaddha SL, Singh TA. Survey of noise assessment and its effect on hearing of workers in ammunition factory. Indian J Indus Med 1977; 17:93-103.

18. Gupta BN, Sen RN, Singh H. Investigations in occupational hearing impairment noise in a nitric acid plant. Chief Advisor Factory Publication: Rep. No. 24; 1972.

19. Sinha YN. Occupational health problems in petroleum refineries. Indian Saf Chr 1991;21:24-8.

20. Santra SC. Status of noise pollution studies in Calcutta and current state of legal measures for abatement. In: Proceeding of the National Workshop on Environmental Statistics, Goa, Central Statistical Organization, Department of Statistics. Ministry of Planning and Programme implementation. Government of India: New Delhi; 1998. p. 79-89.

21. Sharma PD. Environmental biology and toxicology. Rastogi and Company: Meerut, India; 1993.

22. Michael PL. Physics of sound. In: The industrial environment: Its Evaluation and Control, U. S. Dept. of Health and Human Services, Public Health Service, Centre for Disease Control, National Institute for Occupational Safety and Health: 1973. p. 321-31.

Source of Support: Nil, Conflict of Interest: None declared. 